Tropical Journal of Pharmaceutical Research October 2013; 12 (5): 699-704

ISSN: $1596-5996$ (print); 1596-9827 (electronic)

(c) Pharmacotherapy Group, Faculty of Pharmacy, University of Benin, Benin City, 300001 Nigeria.

All rights reserved.

Available online at http://www.tjpr.org

Original Research Article

http://dx.doi.org/10.4314/tjpr.v12i5.6

\title{
Production of Methioninase from Serratia Marcescens Isolated from Soil and its Anti-Cancer Activity against Dalton's Lymphoma Ascitic (DLA) and Ehrlich Ascitic Carcinoma (EAC) in Swiss Albino Mice
}

\author{
William Arputha Sundar ${ }^{1^{*}}$ and Hariharan Nellaiah ${ }^{2}$ \\ ${ }^{1}$ Sankaralingam Bhuvaneswari College of Pharmacy, Anaikuttam, Sivakasi - 626130, ${ }^{2}$ Department of Biotechnology, \\ Kalasalingam University, Anand Nagar, Krishnankoil - 626126, Tamilnadu, India. \\ *For correspondence: Email: williamas@rediffmail.com; Tel: +91-9600338289
}

Revised accepted: 25 June 2013

\begin{abstract}
Purpose: To evaluate the anticancer activity of an enzyme, methioninase, obtained from a soil isolate, Serratia marcesens, against Dalton's lymphoma ascitic (DLA) and Ehrlich ascitic carcinoma (EAC) in Swiss albino mice.

Methods: Cancer was induced using DLA and EAC cells in Swiss albino mice by intraperitoneal injection. The mice were then treated with 10 and $20 \mathrm{mg} / \mathrm{kg}$ body weight of methioninase; 5-fluorouracil (5-FU) was used as standard.

Results: The results showed good improvement in haematological parameters, improvement serum enzymes and lipid profile, as well as increase in life span by up to $77 \%$, increase in body weight $(p<0.01)$, decrease in cancer cell count from $(2.70 \pm 0.40) \times 10^{6}$ to $(1.86 \pm 0.30) \times 10^{6}$ cells $/ \mathrm{ml}$ compared to $(2.70 \pm$ $0.40) \times 10^{6}$ to $(1.42 \pm 0.25) \times 10^{6}$ cells $/ \mathrm{ml}$ for the group treated with 5 -FU. Solid tumor volume decreased from $5.82 \pm 0.15$ to $4.10 \pm 0.11 \mathrm{ml}$ as as against a decrease from $5.82 \pm 0.40$ to $3.56 \pm 0.28$ for the group treated with 5-FU.

Conclusion: The isolated enzyme, methioninase, has a good anti-cancer activity and needs to be further be investigated for this activity.
\end{abstract}

Keywords: Methioninase, Anticancer, Serum depletion, Tumor, Dalton's lymphoma ascetic, Ehrlich ascitic carcinoma

Tropical Journal of Pharmaceutical Research is indexed by Science Citation Index (SciSearch), Scopus, International Pharmaceutical Abstract, Chemical Abstracts, Embase, Index Copernicus, EBSCO, African Index Medicus, JournalSeek, Journal Citation Reports/Science Edition, Directory of Open Access Journals (DOAJ), African Journal Online, Bioline International, Open-J-Gate and Pharmacy Abstracts

\section{INTRODUCTION}

Cancer is a disease characterized by abnormal proliferation of cells. It is one of the leading causes of death in the world, and it is of serious to people living in both the developing and developed nations [1]. Both benign and malignant tumors manifest as uncontrolled proliferation, but the latter are distinguished by their capacity to dedifferentiate, their invasiveness and their ability to metastasise.
Cancer can be cured without much problem if it is diagnosed at the earlier stages. The treatments include chemotherapy, radiation and other forms of therapy. Every therapy has its own advantages and disadvantages.

Nutritional starvation of cancer cells have been tried by many researchers and have been found to be successful in a few cases. Cancer cells have absolute requirements for nutrition, a few of its nutrients it can synthesize and for a few 
others it depends on the host cell. Amino acids like methionine and asparagine come under these categories [2,3]. If the cancer cells are deprived of these amino acids, they starve to death, since they can't synthesize these amino acids [4]. Nutritional starvation can be done by two ways, one by controlling the dietary intake of these amino acids and the other by decreasing the serum concentration of these amino acids.

Previous literatures have shown that dietary methionine starvation extended the life span of tumor bearing animals and lowered the metastatic rate of the methionine dependent tumor. However, dietary methionine starvation is insufficient to completely arrest tumor growth. Depleting serum concentration can be done by the administration of the enzyme, methioninase, which can cleave methionine to $\alpha$ - ketobutyrate, methanethiol and ammonia [5]. In our study, we have isolated a bacterium from soil which has the capability of producing methioninase and this enzyme was purified. The objective of the study was to evaluate the anti tumor activity of methioninase against Daltons Lymphoma Ascitic and Ehrlich Ascitic Carcinoma in Swiss albino mice.

\section{EXPERIMENTAL}

For the study of anticancer activity, an experimental model was selected in such that it would satisfy the following conditions such as: the animal should develop cancer rapidly and reproducibly, pathological changes in the site of induction should result from cancer formation, the symptoms should be ameliorated or prevented by a drug treatment effective in human beings, the drug tested should be administered orally and drug dosage should approximate the optimum therapeutic range for humans, when the dose is scaled with respect to the test animal weight. The study was carried out after obtaining permission from the Institutional Animal Ethical Committee (Reg No: 661/02/c/CPCSEA, approval ref no. A.S. William/200801212/KU/ IAEC/KMCP/43/2013) and OECD guidelines 451 were adhered to in the study [6].

\section{Selection, grouping and acclimatization of laboratory animal}

Male Swiss albino mice (weighing 20 - $25 \mathrm{~g}$ each) were procured from the animal experimentation laboratory of K.M. College of Pharmacy, Madurai, India and used throughout the study. They were housed in micro nylon boxes in a controlled environment $\left(25 \pm 2{ }^{0} \mathrm{C}\right)$ and $12 \mathrm{~h} / 12 \mathrm{~h}$ dark/light cycle with standard laboratory diet and water ad libitum [7]. The study was conducted after obtaining institutional animal ethical committee clearance. As per the standard practice, the mice were segregated based on their gender and quarantined for 15 days before commencement of the experiment. They were maintained in a hygienic environment in the animal house.

\section{Induction of tumor}

Various techniques for induction of cancer in animals, viz, chemically-induced (using DMBA/croton oil, etc) [8], virus-induced, cellinduced (sarcoma - 180, ULCA fibro sarcoma and Jensen sarcoma, mouse lung fibroblast cells L-929, DLA and EAC) [9-11] methods have been used in various experimental studies of anticancer activity. In the present study, cell lines were used to induce cancer in mice and used to evaluate anticancer activity.

Dalton's lymphoma ascitic (DLA) and Ehrlich ascitic carcinoma (EAC) cells were procured from Amla Cancer Research Center, Trissur, Kerala, India. The cells were maintained in vivo in Swiss albino mice by intraperitonial transplantation. While transforming the tumor cells to the grouped animals, the DLA cells and EAC cells were aspirated from the peritoneal cavity of the mice using saline with a no: 26 gauge needle attached to a $1 \mathrm{ml}$ syringe. The cell counts were noted and further dilutions were made so that the total cells were $1 \times 10^{6}$, and given intraperitonially. The tumor was allowed to grow in the mice for a minimum of seven days before commencing the study.

\section{Treatment protocol for Dalton's lymphoma ascitic (DLA) cells}

Swiss albino mice were divided into four groups of six animals each (Table 1). All the animals in the three groups were injected with Dalton's lymphoma ascitic (DLA) cells $\left(1 \times 10^{6}\right.$ cells $/ \mathrm{ml} / \mathrm{mouse})$, intraperitoneally, and the remaining group was normal control.

Table 1: Grouping of animals

\begin{tabular}{|c|c|c|}
\hline $\mathrm{S} / \mathrm{N}$ & Group & Name \\
\hline 1 & $T$ & Normal control \\
\hline 2 & II & Tumor control \\
\hline 3 & III & $\begin{array}{l}\text { control group, treated with 5- } \\
\text { flourouracil at } 20 \mathrm{mg} / \mathrm{kg} \text { body weight, } \\
\text { i.p. [12] }\end{array}$ \\
\hline 4 & IV & $\begin{array}{l}\text { Treatment control, administered } \\
\text { methioninase in a dose of } 10 \mathrm{mg} / \mathrm{kg} \\
\text { body weight, i.p. }\end{array}$ \\
\hline 5 & IV & $\begin{array}{l}\text { Treatment group, administered } \\
\text { methioninase in a dose of } 20 \mathrm{mg} / \mathrm{kg} \\
\text { body weight, i.p. }\end{array}$ \\
\hline
\end{tabular}


In this study, drug treatment was given after $24 \mathrm{~h}$ of inoculation, once daily for 14 days. After the last dose was given on the $14^{\text {th }}$ day, all mice from each group were sacrificed by euthanasia. Blood was withdrawn from each mouse by retro orbital puncture technique and hematological parameters, namely, WBC count, RBC count, haemoglobin content, platelet count and packed cell volume were determined. Serum enzyme and lipid profiles were assessed to determine total cholesterol, triglyceride, alanine amino transferase, alkaline phosphatase, and aspartate amino transferase. All the biochemical investigations were done by using COBAS MIRA PLUS - S autoanalyser (Roche, Switzerland) while haematological parameters were obtained using COBAS MICROS OT 18 (Roche, Switzerland). The animals were also monitored for these parameters as well as for other parameters - body weight, life span and cancer cell count.

\section{Cancer cell count}

The fluid $(0.1 \mathrm{ml})$ from the peritoneal cavity of each mouse was withdrawn with sterile syringe and diluted with $0.8 \mathrm{ml}$ of sterile phosphate buffer solution or ice cold normal saline and $0.1 \mathrm{ml}$ of tryphan blue $(0.1 \mathrm{mg} / \mathrm{ml})$ and the total number of viable cells were counted using haemocytometer by trypan blue dye exclusion method [13].

\section{Treatment protocol for Ehrlich ascitic carcinoma (EAC) cells}

Swiss albino mice were divided into three groups $(n=6)$. Tumor cells $\left(1 \times 10^{6}\right.$ cells/mouse) were injected into the right limb (thigh) of all the animals intramuscularly except one group which served as control. The mice in Group I were tumor control, Group II was control treated with $5-\mathrm{FU}$ at $20 \mathrm{mg} / \mathrm{kg}$ body weight. Groups III and IV received methioninase [14] at a dose of 10 and $20 \mathrm{mg} / \mathrm{kg}$ orally on 5 alternative days. Tumor mass was measured from the $11^{\text {th }}$ day of tumor induction. The diameter of the tumor was measured on every $5^{\text {th }}$ day for a period of 30 days using Vernier callipers and the volume of the tumor mass was calculated using the formula $V=4 / 3 \pi r^{2}$, where $r$ is the mean of $r^{1}$ and $r^{2}$, which are two independent radii of the tumor mass.

\section{Data analysis}

The results were expressed as mean \pm standard error of the mean (SEM). Statistical significance was assessed using one-way analysis of variance (ANOVA) followed by Newmann Keul's multiple range test; $p<0.05$ was taken as the level of significance.

\section{RESULTS}

\section{Effect of $L$. methioninase on the haema- tological parameters: of mice with DLA cells}

The results of the haematological studies are shown in Table 2. RBC content, haemoglobin level and platelet counts lower while WBC count significantly was higher in the DLA control group than in the normal control group. Treatment with methioninase at a dose of 10 and $20 \mathrm{mg} / \mathrm{kg}$ significantly increased haemoglobin content $(p<$ 0.01 ) from $7.32 \pm 0.92$ to $10.60 \pm 1.32$ and $10.30 \pm$ 0.98 , respectively, compared to $11.80 \pm 1.56$ for 5 -FU control group. The RBC content was increased significantly $(p<0.01)$ from $2.44 \pm$ 0.50 in DLA control to $3.34 \pm 0.70$ and $3.10 \pm$ 0.52 in mice-treated at methioninase doses of 10 and $20 \mathrm{mg} / \mathrm{kg}$ as compared to $4.16 \pm 0.90$ for 5 FU standard control. Platelet count rose significantly $(p<0.01)$ from $1.72 \pm 0.62$ for DLA control to $2.12 \pm 0.80$ and $2.30 \pm 0.92$ in mice treated with methioninase at 10 and $20 \mathrm{mg} / \mathrm{kg}$ doses compared to $2.80 \pm 0.90$ for $5-\mathrm{FU}$ standard group. A significant reduction in WBC count $(p<0.01)$ from $14.08 \pm 2.40$ for DLA control to $12.60 \pm 1.96$ and $12.15 \pm 1.55$ in mice treated with methioninase at 10 and $20 \mathrm{mg} / \mathrm{kg}$ doses compared to $11.35 \pm 1.85$ for 5 -FU standard. These results suggest that methioninase exerts good anticancer activity against DLA, although it was not as strong as that of the standard, 5-FU, at a dose of $20 \mathrm{mg} / \mathrm{kg}$.

\section{Effect of L-methioninase on biochemical parameters}

The inoculation of DLA cells caused a significant increase ( $p$-value) in the level of total cholesterol, triglycerides, aspartate amino transferase, alkaline phosphatase and alanine amino transferase in the tumor control animals (G2), when compared to the normal group. Treatment with methioninase from soil at doses of 10 and $20 \mathrm{mg} / \mathrm{kg}$ reversed these changes to normal levels as can be seen in Table 3 . These changes were all significant $(p<0.01)$ when compared with normal or treatment control. Treatment with 5-FU also produced a similar result.

\section{Effect of L-methioninase on DLA-induced tumor}

In the DLA tumor group, the average life span of the animal was $50 \%$ for cancer control animals whereas methioninase-treated animals at doses of 10 and $20 \mathrm{mg} / \mathrm{kg}$ showed increase in life span 
to 72 and $77 \%$, respectively (Table 4 ). The antitumor activity of methioninase was also evident in the significant reduction in the increase in viable tumor cell count $(P<0.01)$ and packed cell volume, $(P<0.01)$ when compared with normal control.

\section{Effect of methioninase on EAC-induced solid tumor}

The solid tumor volume induced by EAC cells significantly increased from day 0 to 30 as can be seen in Table 5. However, tumor volume significantly decreased in animals treated with methioninase from day 15 to the end of the experiment. Approximately 27 and $30 \%$ reduction in tumor volume was observed with 10 and $20 \mathrm{mg} / \mathrm{kg}$ of methioninase doses, respectively, on day 30 of the experiment.

\section{DISCUSSION}

The emergence of drug resistance and adverse effects of available chemotherapeutic agents always necessitates discovery and development of new drugs, targeting new roles and models. Many cancer cells have an absolute requirement for plasma methionine, whereas normal cells are

Table 2: Effect of methioninase derived from soil on haematological parameters $(n=6)$ in DLA tumor bearing mice

\begin{tabular}{|c|c|c|c|c|}
\hline Treatment & $\begin{array}{l}\text { WBC } \\
\text { (cells } \times 10^{3} / \mathrm{ml} \text { ) }\end{array}$ & $\begin{array}{l}\text { RBC count } \\
\left(10^{6} \text { ells } / \mathrm{mm}^{3}\right)\end{array}$ & $\begin{array}{l}\mathrm{Hb} \\
(\mathrm{gm} / \mathrm{dl})\end{array}$ & $\begin{array}{l}\text { Platelets } \\
\left(\text { Lakhs } / \mathrm{mm}^{3}\right)\end{array}$ \\
\hline Normal control & $10.46 \pm 1.58$ & $4.50 \pm 0.96$ & $12.44 \pm 1.30$ & $3.45 \pm 0.90$ \\
\hline Cancer control & $14.08 \pm 2.40^{\mathrm{a}^{* *}}$ & $2.44 \pm 0.50^{\mathrm{a}^{\star \star}}$ & $7.32 \pm 0.92^{\mathrm{a}^{\star \star}}$ & $1.72 \pm 0.62^{\mathrm{a}^{\star \star}}$ \\
\hline $5-F U(20 \mathrm{mg} / \mathrm{kg})$ & $11.35 \pm 1.85^{\mathrm{b}^{* *}}$ & $4.16 \pm 0.90^{\mathrm{b}^{\star \star}}$ & $11.8 \pm 1.56^{\mathrm{b}^{\star \star}}$ & $2.80 \pm 0.90^{\mathrm{b}^{\star \star}}$ \\
\hline Methioninase $(10 \mathrm{mg} / \mathrm{kg})$ & $12.60 \pm 1.96^{\mathrm{b}^{* \star}}$ & $3.34 \pm 0.70^{b^{\star \star}}$ & $10.60 \pm 1.32^{\mathrm{b}^{* *}}$ & $2.12 \pm 0.80^{\mathrm{b}^{\star \star}}$ \\
\hline Methioninase $(20 \mathrm{mg} / \mathrm{kg})$ & $12.15 \pm 1.55^{\mathrm{b}^{* *}}$ & $3.10 \pm 0.52^{b^{\star \star}}$ & $10.30 \pm 0.98^{b^{* *}}$ & $2.30 \pm 0.92^{b^{* *}}$ \\
\hline
\end{tabular}

Table 3: Effect of methioninase from soil on serum enzymes and lipid profile $(n=6)$ in DLA tumor-bearing mice

\begin{tabular}{|c|c|c|c|c|c|}
\hline Treatment & $\begin{array}{l}\text { Cholesterol } \\
\text { (mg/dL) }\end{array}$ & $\begin{array}{l}\text { TGL } \\
(\mathrm{mg} / \mathrm{dL})\end{array}$ & $\begin{array}{l}\text { AST } \\
\text { (U/L) }\end{array}$ & $\begin{array}{l}\text { ALT } \\
\text { (U/L) }\end{array}$ & $\begin{array}{l}\text { ALP } \\
\text { (U/L) }\end{array}$ \\
\hline Norm & $113.30 \pm 3.70$ & $134.90 \pm 2.52$ & $42.65 \pm 1.32$ & $34.50 \pm 1.60$ & $127.40 \pm 2.45$ \\
\hline Canc & $147.9 \pm$ & $224.40 \pm 4.82^{\mathrm{a}^{* *}}$ & $87.4 \pm 2.90^{\mathrm{a}^{\star \star}}$ & $63.22 \pm 2.70^{\mathrm{a}^{\star *}}$ & $240.32 \pm 4.21^{\mathrm{a}^{\star \star}}$ \\
\hline $5-F U(20 \mathrm{mg} / \mathrm{kg})$ & $124.50 \pm 3.85^{b^{* *}}$ & $164.65 \pm 2.42^{\mathrm{b}^{* \star}}$ & $57.42 \pm 1.83^{b^{\star *}}$ & $44.35 \pm 1.75^{\mathrm{b}^{\star *}}$ & $160.30 \pm 2.43^{b^{\star *}}$ \\
\hline Methioninase (10 & $122.50 \pm 3.60^{b^{* *}}$ & $176.70 \pm 2.65^{\mathrm{b}^{\star \star}}$ & $67.45 \pm 1.92^{b^{\star \star}}$ & $47.35 \pm 1.90^{\mathrm{b}^{*}}$ & $192.78 \pm 2.70^{\mathrm{b}^{\star \star}}$ \\
\hline Methioninase (20 mg/kg) & $120.34 \pm 3.53^{b^{* *}}$ & $171.82 \pm 2.55^{\mathrm{b}^{\star \star}}$ & $62.55 \pm 2.32^{b^{\star *}}$ & $46.30 \pm 1.72^{\mathrm{b}^{* *}}$ & $190.43 \pm 2.32^{b^{\star \star}}$ \\
\hline
\end{tabular}

${ }^{\star \star} \mathrm{a}$ - significantly different from control $\left(\mathrm{G}_{1}\right)$ at $p<0.01 ;{ }^{* \star} \mathrm{b}-$ significantly different from cancer control $\left(\mathrm{G}_{2}\right)$ at $p<0.01$

Table 4: Effect of methioninase on the life span, body weight and cancer cell count of tumor-induced mice $(n=6)$

\begin{tabular}{|c|c|c|c|c|}
\hline Treatment & \% ILS/life span & $\begin{array}{c}\text { Increase in body } \\
\text { weight (g) }\end{array}$ & $\begin{array}{c}\text { Cancer cell count } \\
\times 10^{6} \text { cells } / \mathrm{ml}\end{array}$ & $\begin{array}{l}\text { PCV } \\
(\%)\end{array}$ \\
\hline Normal control & $>>30$ days & $2.30 \pm 0.62$ & - & $14.30 \pm 2.45$ \\
\hline Cancer control & $50 \%$ & $7.80 \pm 0.95^{\mathrm{a}^{\star \star}}$ & $2.70 \pm 0.40^{\mathrm{a}^{\star \star}}$ & $30.40 \pm 3.26^{\mathrm{a}^{\star \star}}$ \\
\hline $5-F U(20 \mathrm{mg} / \mathrm{kg})$ & $90 \%$ & $3.75 \pm 0.70^{b^{* *}}$ & $1.42 \pm 0.25^{\mathrm{b}^{\star \star}}$ & $18.26 \pm 1.50^{b^{* *}}$ \\
\hline Methioninase $(10 \mathrm{mg} / \mathrm{kg})$ & $72 \%$ & $4.18 \pm 0.70^{b^{\star *}}$ & $1.86 \pm 0.36^{b^{\star \star}}$ & $22.40 \pm 1.55^{b^{\star *}}$ \\
\hline Methioninase $(20$ mg/kg) & $77 \%$ & $4.30 \pm 0.80^{b^{* *}}$ & $1.76 \pm 0.30^{b^{\star \star}}$ & $24.35 \pm 2.45^{b^{\star \star}}$ \\
\hline
\end{tabular}

${ }^{* \star} \mathrm{a}=$ significantly different from control $\left(\mathrm{G}_{1}\right)$ at $p<0.01 ;{ }^{* *} \mathrm{~b}=$ significantly different from cancer control $\left(\mathrm{G}_{2}\right)$ at $p<0.01$

Table 5: Effect of methioninase on solid tumor volume $(n=6)$ in EAC tumor-bearing mice

\begin{tabular}{llllll}
\hline Treatment & Dose & \multicolumn{3}{l}{ Solid tumor volume } & \\
\cline { 3 - 5 } & & $\mathbf{1 5}^{\text {th }}$ day & $\mathbf{2 0}^{\text {th }}$ day & $\mathbf{2 5}^{\text {th }}$ day & $\mathbf{3 0}^{\text {th }}$ day \\
\hline Cancer control & $2 \mathrm{ml} / \mathrm{kg}$ saline & $2.63 \pm 0.14$ & $3.59 \pm 0.15$ & $4.72 \pm 0.15$ & $5.82 \pm 0.15$ \\
Standard control $(5-\mathrm{FU})$ & $20 \mathrm{mg} / \mathrm{kg}$ & $2.54 \pm 0.15$ & $3.25 \pm 0.22$ & $3.40 \pm 0.24$ & $3.56 \pm 0.28$ \\
Treatment group & $10 \mathrm{mg} / \mathrm{kg}$ methioninase & $2.42 \pm 0.15$ & $3.36 \pm 0.23$ & $3.61 \pm 0.19$ & $4.24 \pm 0.17^{\text {** }}$ \\
Treatment group & $20 \mathrm{mg} / \mathrm{kg}$ methioninase & $2.66 \pm 0.16$ & $3.36 \pm 0.17$ & $3.37 \pm 0.17$ & $4.10 \pm 0.11^{\text {** }}$ \\
\hline \multicolumn{2}{c}{${ }^{* *}$ a significantly different from tumor control $\left(G_{1}\right)$ at $p<0.01$} & &
\end{tabular}


relatively resistant to the restriction of exogenous methionine. This can be achieved by the administration of methioninase, an enzyme which cleaves the dietary methionine. Methionine depletion has broad spectrum of antitumor activity.

In the present study, we have induced cancer by using DLA and EAC cell lines. The cancerinduced mice were treated with methioninase at doses of 10 and $20 \mathrm{mg} / \mathrm{kg}$. In DLA tumor-bearing animals, a rapid increase in the ascitic tumor volume was observed. Ascitic fluid is a direct nutritional source for tumor cells and therefore a rapid increase in ascitic fluid with tumor growth would be a means to meet the nutritional requirement of the tumor cells. Treatment with methioninase inhibited viable tumor cell count, solid tumor volume and increased the life span of the tumor bearing mice possibly by causing nutrition starvation for the enzyme methionine.

The criteria for judging the value of any anticancer drug is the prolongation of the life span of animals. It may be concluded that methioninase, by decreasing the nutritional fluid volume and arresting tumor growth, increases the life span of DLA bearing mice. There was also a reduction in solid tumor volume of EAC bearing mice indicating that methioninase is involved in the reduction of tumor. Usually in cancer chemotherapy, the major problems that are encountered are myleo-suppression and anaemia $[15,16]$. The anaemia encountered in tumor-bearing mice is mainly due to reduction in $\mathrm{RBC}$ or haemoglobin and this may occur either due to iron deficiency or to haemolytic or myleopathic conditions. Treatment with methioninase restored haemoglobin content, RBC and WBC count to more or less normal levels. This indicates that methioninase has protective effect on the hematopoietic system.

It has been reported that the presence of tumor in human body or in experimental animals is known to affect many functions of the liver [17]. The significantly elevated levels of total cholesterol, triglycerides, aspartate amino transferase, alkaline phosphatase, alanine amino transferase in the serum of tumor inoculated animals indicate liver damage and loss of functional integrity of cell membrane. In the present study, the marked biochemical changes in DLA inoculated animals indicate the toxic effect produce in the animals by the tumor. The normalization of these effects observed in the serum of animals treated with methioninase supports the potent anti tumor and hepatoprotective effects of methioninase isolated from soil.
The significant reduction in the volume of solid tumor shows that the methioninase exerts a potent cytotoxic activity against solid tumors. Where there is methionine depletion, cancer cells are arrested in the late S-G2 phase due to pleiotropic effect and they undergo apoptosis. From the above results it can be found that methioninase isolated from soil bacterium shows potentials for the treatment of a wide range of tumors.

\section{CONCLUSION}

The isolated enzyme methioninase has been found to possess significant antitumor activity and increased life span of tumor bearing mice. Further investigations are in progress in our laboratory to optimize the medium composition for the maximum production of the enzyme.

\section{REFERENCES}

1. Rang HP, Dale MM, Ritter JM, Flower RJ. In Rang and Dale's Pharmacology. $6^{\text {th }}$ ed. Churchill Livingston; 2007; $p 718$.

2. Lishko VK, Lishko OV, Hoffman RM. The preparation of endotoxin-free L-Methionine- $\alpha$-deamino- $\gamma$ mercaptomethane-lyase (L-Methioninase) from Pseudomonas putida. Protein expression and purification 1993; 4: 529-533.

3. Hoshiya $Y$, Guo $H$, Kubota $T$, Inada $T$, Asanuma $F$, Yamada $Y$, Koh J, Kitojima $M$, Hoffman RM. Human tumors are methionine dependent in vivo. Anticancer research 1995; 15: 717-718.

4. Lishko VK, Lishko OV, Hoffman RM. Depletion of serum methionine by methioninase in mice. Anticancer Res 1993; 13: 1465-1468.

5. Ito $S$, Nakamura $T$, Eguchi $Y$. Purification and characterization of methioninase from Pseudomonas putida. J Biochem 1976; 79: 12631272.

6. Organization for the economic cooperation and development. Test No: 451: carcinogenicity studies. OECD guidelines for testing of chemicals 2010; 1: 1-15.

7. Unnikrishnan MC, Kuttan R. Tumor reducing and AntiCarcinogenic activity of selected species. Cancer Letters 1990; 51: 85-89.

8. Agarwal $R C$, Jain $R$, Raju $W$, Ovais M. AntiCarcinogenic effects of Solanum lycopersicum fruit extract on Swiss albino and C57B1 Mice. Asian. Pacific J. Cancer Prev 2009; 10: 379-382.

9. Bezerra DP, Castro FO, Alves APNN, Pessoa $C$, Moraes MO, Silveria ER, Lima MAS, Elmiro FJM, Costa-Lotufo LV. In vivo growth - inhibition of sarcoma 180 by piplartine and piperine two alkaloid amides from piper. Braz JMedBiol Res 2006; 39(6): 801-807.

10. Appleman D, Skavinski ER, Stein AM. Catalase studies on normal and cancerous rats. Cancer Res 1950; 10: 498-505.

11. Chitra V, Sharma S, Kayande N. Evaluation of anticancer activity of Vitex negundo in experimental animals: an invitro and invivo study, International Journal of PharmTech Research 2009; 1(4): 14851489.

12. Sathiyanarayanan L, Shinnathambi, Arulmozi, Chidhambarnathan N. Anticarcinogenic activity of Leptadenia reticulata against Dalton's ascitic 
Iymphoma. Iranian Journal of Pharmacology and Therapeutics2006; 6: 133-136.

13. Mary KT, Girija K, Ramadasan K. Partial purification of tumor reducing principle from Helicanthis elasticus. Cancer Letters 1994; 81: 53-57.

14. William AS, Nellaiah H. A rapid method for screening of methioninase producing Serratia marcescens species from soil. Int J Pharm Pharm Sci 2013; 5(2): 426-427.
15. Hogland HC. Haematological complication of cancer chemotherapy. Semin Oncol 1982; 9: 95-102.

16. Price VE, Greenfield RE. Anaemia in cancer. Adv Can Res 1958; 5: 199-200.

17. DeWys WD. Pathophysiology of cancer cachexia: Current understanding and areas of future research. Cancer Res 1982; 42: 721-726. 